\title{
PENGARUH KUALITAS PELAYANAN TERHADAP KEPUASAN PASIEN DI PUSKESMAS CIBITUNG KABUPATEN SUKABUMI
}

\section{THE INFLUENCE OF SERVICE QUALITY ON PATIENT SATISFACTION IN CIBITUNG'S COMMUNITY HEALTH CENTER OF SUKABUMI REGENCY}

\author{
Engkus ${ }^{1 *}$ \\ 1Jurusan Administrasi Publik, Fakultas Ilmu Sosial dan Ilmu Politik, Universitas Islam Negeri \\ (UIN) Sunan Gunung Djati (SGD) Bandung. Jl. A. H. Nasution 105, Bandung 40614 \\ *Korespondensi: Engkus. Email: engkus@uinsgd.ac.id
}

(Diterima: 05-09-2019; Ditelaah: 16-09-2019; Disetujui: 25-09-2019)

\begin{abstract}
The main problem of Cibitung's Community Health Center in Sukabumi Regency is the lack of service quality caused by human resources, facilities, and referrals that have not been optimal yet. The research aims to analyze the influence of service quality on patient satisfaction. The method of the research is the quantitative approach with associative method to analyze two variables, namely service quality and patient satisfaction. The results of the research indicate that the validity and reliability tests are valid and reliable with value of $r$ table 0.195 . The results of questionnaire data processing and the answers of respondents regarding service quality show the effective criteria $82.4 \%$. The results of questionnaire data processing and the answers of respondents regarding patient satisfaction show the effective criteria $81.4 \%$. The t test indicates that value of $t>t$ table is obtained $(11.955>1.988)$. It means that there is partially a significant influence of service quality on patient satisfaction, then Ho is rejected. The correlation analysis of $\mathrm{R}$ obtains 0.772 , indicating that there is a strong relationship of service quality to patient satisfaction. The result of coefficient determination obtains $\mathrm{R}$ square score 0.596 or $59.6 \%$, therefore the contribution percentage of service quality variable to patient satisfaction variable is $59.6 \%$, included in the high effective criteria. The conclusion is that there is a strong influence of service quality on patient satisfaction in Cibitung's Community Health Center of Sukabumi Regency.
\end{abstract}

Keywords: Facilities, Patient Satisfaction, Service Quality.

\begin{abstract}
ABSTRAK
Masalah utama Pusat Kesehatan Masyarakat Cibitung Kabupaten Sukabumi adalah kualitas layanan, yang disebabkan oleh sumber daya manusia, fasilitas, dan rujukan yang belum optimal. Penelitian ini bertujuan untuk menganalisis pengaruh kualitas pelayanan terhadap kepuasan pasien. Metode penelitian yang digunakan adalah kuantitatif dengan metode asosiatif untuk mengetahui hubungan antara variabel kualitas pelayanan dengan variabel kepuasan pasien. Hasil penelitian, yaitu uji validitas dan reliabilitas, valid dan reliabel dengan nilai $r$ tabel 0,195 ; hasil pengolahan data kuesioner dan tanggapan responden mengenai kualitas layanan yang dihasilkan dengan kriteria efektif $82,4 \%$, sedangkan tanggapan responden tentang kepuasan pasien dengan kriteria efektif 81,4\%. Dalam uji $t$, nilai $t>t$ tabel diperoleh $(11,955>1,988)$. Terkait dengan analisis korelasi parsial terdapat pengaruh yang signifikan antara kualitas pelayanan terhadap kepuasan pasien, maka Ho ditolak. Dari hasil analisis diperoleh R sebesar 0,772, yang menunjukkan terdapat hubungan yang kuat antara kualitas layanan dan kepuasan pasien. Hasil koefisien determinasi menunjukkan angka R kuadrat sebesar 0,596 atau 59,6\%, dengan demikian persentase kontribusi variabel kualitas pelayanan terhadap kepuasan pasien sebesar 59,6\% termasuk dalam kriteria efektif tinggi. Dapat disimpulkan bahwa terdapat pengaruh yang kuat dari kualitas layanan terhadap kepuasan pasien di Puskesmas Cibitung, Kabupaten Sukabumi.
\end{abstract}

Kata Kunci: Fasilitas, Kepuasan Pasien, Kualitas Pelayanan.

Engkus. 2019. Pengaruh Kualitas Pelayanan terhadap Kepuasan Pasien di Puskesmas Cibitung Kabupaten Sukabumi. 


\section{PENDAHULUAN}

Pemerintah telah menyelenggarakan pelayanan kesehatan mulai dari pelayanan kesehatan primer di tingkat Pusat Kesehatan Masyarakat (Puskesmas), pelayanan kesehatan sekunder di tingkat pelayanan rumah sakit dengan pelayanan spesialis, dan pelayanan kesehatan tertier yaitu rumah sakit dengan pelayanan sub spesialis.

Sebagai unit pelayanan kesehatan primer yang merupakan salah satu pelayanan publik terdepan Pemerintah Kabupaten/Kota, puskesmas harus lebih di perhatikan terutama berkaitan dengan kualitas pelayanan kesehatannya sehingga dalam hal ini puskesmas dituntut untuk selalu meningkatkan profesionalitas dari pegawainya serta meningkatkan fasilitas atau sarana kesehatannya, sebagaimana Undang-Undang Nomor 36 Tahun 2009 dalam Pasal 1 tentang fasilitas pelayanan kesehatan adalah suatu alat atau tempat yang digunakan untuk menyelenggarakan upaya pelayanan kesehatan, baik promotif, preventif, kuratif maupun rehabilitatif yang dilakukan oleh pemerintah, pemerintah daerah, dan masyarakat.

Dalam memberikan pelayanan tentu harapannya ingin memberikan kepuasan terhadap pasien, karena kepuasan pasien itu sendiri merupakan keluaran (outcome) dari layanan kesehatan. Dengan demikian kepuasan pasien merupakan salah satu tujuan peningkatan mutu layanan kesehatan. Jika pasien merasa puas pasien akan terus berkelanjutan melakukan pengobatan di Rumah sakit atau Puskesmas tersebut tetapi jika pasien merasa tidak puas pasien akan menceritakan pengalaman buruknya kepada setiap orang.

Salah satu upaya meningkatkan kualitas pelayanan kesehatan adalah harus di terapkannya Standar Pelayanan Minimal (SPM) yaitu jenis dan mutu pelayanan dasar yang merupakan urusan pemerintahan wajib yang diselenggarakan pemerintah provinsi maupun pemerintah daerah yang berhak di peroleh setiap warga negara secara minimal seperti pelayanan kesehatan di daerah yaitu pelayanan kesehatan ibu hamil, pelayanan kesehatan ibu bersalin, pelayanan kesehatan bayi baru lahir, dan pelayanan kesehatan pada usia pendidikan dasar sebagaimana Peraturan Pemerintah Nomor 65 Tahun 2005 tentang Pedoman Penyusunan dan Penerapan.

Puskesmas Cibitung merupakan salah satu puskesmas yang ada di Kecamatan Cibitung Kabupaten Sukabumi yang mempunyai Visi "Mewujudkan Kecamatan Cibitung Sehat, Mandiri, Berkeahlian dan Relijius" dan Misi sebagai berikut:

1. Memelihara dan meningkatkan mutu pelayanan kesehatan dasar.

2. Mengupayakan pelayanan kesehatan yang ramah, empati dan relijius.

3. Memelihara dan meningkatkan kesehatan perorangan, keluarga, dan masyarakat yang bermutu dan berkeahlian.

4. Mendorong kemandirian hidup sehat bagi individu, keluarga dan masyarakat.

Pelayanan yang terdapat di Puskesmas Cibitung Kabupaten Sukabumi terdiri dari 11 jenis pelayanan sebagai berikut:

Tabel 1. Jenis Pelayanan di Puskesmas Cibitung Kabupaten Sukabumi

\begin{tabular}{cl}
\hline No. & Jenis Pelayanan \\
\hline 1. & Pendaftaran \\
\hline 2. & (Instalasi Gawat Darurat) IGD \\
\hline 3. & Pemeriksaan \\
\hline 4. & Persalinan \\
\hline 5. & KIA (Kesehatan Ibu dan Anak) dan KB \\
\hline 6. & Farmasi \\
\hline 7. & Gizi \\
\hline 8. & Gigi \\
\hline 9. & Kesehatan Lingkungan \\
\hline 10. & Imunisasi Vaksin \\
\hline 11 & TB Paru \\
\hline
\end{tabular}

Sumber: Puskesmas Cibitung Kabupaten Sukabumi, 2018

Kualitas pelayanan yang disediakan oleh Puskesmas Cibitung Kabupaten Sukabumi belum dilaksanakan secara optimal. Secara umum masih terdapat kekurangan. Berdasarkan observasi yang 
peneliti lakukan kurang lebih selama 6 bulan dimana peneliti melihat langsung proses pelayanan kesehatan pada Puskesmas Cibitung Kabupaten Sukabumi, peneliti menemukan beberapa masalah yang merujuk ke dalam dimensi kepuasan pasien sebagai berikut:

1) Terkait dengan akses layanan kesehatan, fasilitas ruangan yang tidak memadai seperti satu ruangan digunakan untuk dua pemeriksaan yaitu pemeriksaan gigi dan IGD.

2) Terkait dengan mutu layanan kesehatan, tidak adanya dokter dan pemberian obat yang itu-itu saja.

3) Terkait dengan proses layanan kesehatan, lambatnya dalam pelayanan.

4) Terkait dengan sistem layanan kesehatan, pembuatan rujukan BPJS yang cukup lama karena jaringan internet yang buruk.

\section{MATERI DAN METODE}

\section{Konsep/Teori yang Relevan}

Ada dua konsep yang hendak dilihat hubungan dan dampaknya, yaitu kualitas pelayanan dan kepuasan pasien.

\section{Kualitas Pelayanan}

Pelayanan merupakan suatu kegiatan yang dilakukan oleh seseorang atau kelompok dalam memberikan kepuasan kepada yang menerima pelayanan. Pelayanan berlangsung secara rutin dan berkesinambungan meliputi seluruh kehidupan orang dalam masyarakat. Berkaitan dengan pelayanan terdapat dua istilah yang perlu diketahui yaitu melayani dan pelayanan. Pengertian melayani ialah "membantu menyiapkan (mengurus) apa yang diperlukan seseorang".

Sedangkan pengertian pelayanan itu sendiri adalah "usaha yang melayani kebutuhan orang lain". Pada dasarnya manusia dalam memenuhi kebutuhan hidupnya membutuhkan orang lain, sehingga pelayanan dapat diartikan sebagai suatu kegiatan yang bertujuan membantu menyiapkan atau mengurus apa yang dibutuhkan oleh orang lain. Sehingga pelayanan senantiasa berhubungan dengan kepentingan publik.

Pengertian kualitas menurut Fandy Tjiptono (Hardiansyah, 2011: 40) berkaitan dengan:

1) Kesesuaian dengan persyaratan.

2) Kecocokan untuk pemakaian.

3) Perbaikan berkelanjutan.

4) Bebas dari kerusakan/cacat.

5) Pemenuhan kebutuhan pelanggan sejak awal dqan setiap saat.

6) Melakukan segala sesuatu secara benar.

7) Sesuatu yang bisa membahagiakan pelanggan.

Konsep kualitas pelayanan dapat dipahami melalaui perilaku yang dimainkan oleh konsumen daam mencari, membeli, menggunakan dan mengevaluasi suatu produk maupun pelayanan yang diharapkan dapat memuaskan kebutuhan mereka.

Menurut Ibrahim (Hardiansyah, 2011: 40), kualitas pelayanan publik merupakan suatu kondisi dinamis yang berhubungan dengan produk, jasa, manusia, proses dan lingkungan dimana penilaian kualitasnya ditentukan pada saat terjadinya pemberian pelayanan publik tersebut.

Menurut Kotler (2000: 25), kualitas pelayanan merupakan totalitas dari bentuk karakteristik barang dan jasa yang menunjukkan kemampuannya untuk memuaskan kebutuhan pelanggan, baik yang nampak jelas maupun yang tersembunyi.

Menurut Zeithaml, dkk (Hardiansyah, 2011), kualitas pelayanan dapat diukur dari 5 dimensi, yaitu:

1) Tangible (Berwujud), yaitu kemampuan menunjukkan eksistensinya kepada pihak eksternal. Penampilan dan kemampuan sarana dan prasarana fisik perusahaan yang dapat diandalkan keadaan lingkungan sekitarnya merupakan bukti nyata dari pelayanan yang diberikan oleh para pemberi jasa. Hal ini meliputi fasilitas fisik contoh gedung, gudang, dan lain-lainya, perlengkapan dan peralatan yang 
digunakan (teknologi) serta penampilan pegawai.

2) Reliability (Kehandalan), yaitu kemampuan perusahaan untuk memberikan pelayanan sesuai dengan yang dijanjikan seacara akurat dan terpercaya. Kinerja harus sesuai dengan harapan pelanggan yang berarti ketetapan waktu, pelayanan yang sama untuk semua pelanggan tanpa kesalahan, sikap yang simpatik dan dengan akurasi yang tinggi.

3) Responsiviness (Respon/Ketanggapan), yakni kebijakan untuk membantu dan memberikan pelayanan yang cepat dan tepat kepada pelanggan dengan penyampaian informasi yang jelas. Membiarkan konsumen menunggu persepsi yang negative dalam kualitas pelayanan.

4) Assurance (Jaminan), yakni pengetahuan, kesopansantunan dan kemampuan para pegawai perusahaan untuk menumbuhkan rasa percaya para pelanggan kepada perusahaan. Antara lain komunikasi, kredibilitas, keamanan, kompetensi, dan sopan santun.

5) Empathy (Empati), yaitu perhatian yang tulus dan bersifat individual atau pribadi yang diberikan kepada para pelanggan dengan berupa memahami keinginan konsumen. Dimana suatu perusahaan diharapkan memiliki pengertian dan pengetahuan tentang pelanggan, memahami kebutuhan pelanggan secara spesifik, serta memiliki waktu pengoperasian yang nyaman bagi pelanggan.

Faktor-faktor yang mempengaruhi kualitas pelayanan menurut Hardiyansyah (2011: 65) sebagai berikut:

1) Motivasi kerja birokrasi dan aparatur.

2) Kemampuan aparatur.

3) Pengawasan/kontrol sosial.

4) Perilaku birokrasi/aparatur.

5) Komunikasi, disposisi dan struktur birokrasi.

6) Kinerja birokrasi.

\section{Kepuasan Pasien}

Memahami kebutuhan dan keinginan pasien adalah hal penting yang mempengaruhi kepuasan pasien. Pasien yang puas merupakan aset yang sangat berharga karena apabila pasien merasa puas mereka akan terus melakukan pemakaian terhadap jasa pilihannya, tetapi jika pasien merasa tidak puas mereka akan memberitahukan dua kali lebih hebat kepada orang lain tentang pengalaman buruknya.

Pasien adalah orang sakit yang di rawat dokter dan tenaga kesehatan lainnya di tempat praktek (Yuwono, 2003). Sedangkan kepuasan adalah perasaan senang seseorang yang berasal dari perbandingan antara kesenangan terhadap aktivitas dan suatu produk dengan harapannya (Nursalam, 2011).

Menurut Imbalo S. Pohan (2015: 156), kepuasan pasien adalah suatu tingkat perasaan pasien yang timbul sebagai akibat dari kinerja layanan kesehatan yang diperolehnya setelah pasien membandingkannya dengan apa yang diharapkannya.

Untuk mengukur kepuasan pasien menurut Imbalo S. Pohan (2015: 152) ada empat dimensi sebagai berikut:

1) Akses layanan kesehatan, yaitu pelayanan yang harus dapat dicapai oleh masyarakat, tidak terhalang oleh keadaan geografis, sosial, ekonomi, organisasi dan bahasa.

2) Mutu layanan kesehatan, yaitu pelayanan kesehatan yang dapat memuaskan setiap pemakai jasa pelayanan kesehatan yang sesuai dengan tingkat kepuasan rata-rata.

3) Proses layanan kesehatan, yaitu berbagai kegiatan dalam pelayanan kesehatan yang dapat menghasilakan kepuasan sesuai yang di harapkan pasien.

4) Sistem layanan kesehatan, yakni bagian penting dalam meningkatkan derajat kesehatan. Melalui sistem ini tujuan pembangunan kesehtan dapat tercapai 
dengan cara efektif, efisien dan tepat sasaran.

Terdapat faktor-faktor yang mempengaruhi kepuasan pasien. Kepuasan pasien harus disertai dengan pemantauan terhadap kebutuhan dan keinginan yaitu:

1) Kinerja, yaitu karakteristik operasi pokok dari inti yang dibeli atau diterima.

2) Ciri-ciri atau keistimewaan tambahan, yakni karakteristik sekunder atau pelengkap.

3) Kehandalan (reliability), yaitu faktor kemungkinan yang menggambarkan adanya kemungkinan kecil akan mengalami kerusakan atau gagal pakai.

4) Kesesuaian dengan spesifikasi, yaitu sejauhmana karakteristik desain dan operasi memenuhi standar-standar yang telah ditetapkan sebelumnya.

5) Daya tahan (durability), berkaitan dengan beberapa lama produk atau jasa tersebut dapat terus digunakan.

6) Serviceability, meliputi kecepatan kompetensi, kenyamanan, mudah diperbaiki, serta penanganan keluhan yang memuaskan. Pelayanan yang diberikan tidak sebatas hanya sebelum penjualan tetapi juga selama proses penjualan hingga purna jual, mencakup pelayanan perbaikan dan ketersediaan komponen yang dibutuhkan.

7) Estetika, yaitu daya tarik produk terhadap panca indera.

8) Kualitas yang dipersepsikan, berkaitan dengan citra dan reputasi produk atau jasa serta tanggung jawan perusahaan terhadapnya. Biasanya karena kurang pengetahuan konsumen akan atribut atau ciri produk (barang atau jasa) yang akan dibeli atau diterima.

\section{Metode}

Pendekatan penelitian yang digunakan adalah pendekatan kuantitatif, yaitu pendekatan yang menilai suatu kegiatan yang dinyatakan dalam bentuk angka. Metode penelitian yang digunakan adalah metode penelitian asosiatif atau hubungan fungsional.

Menurut Sugiyono (2017), penelitian asosiatif merupakan penelitian yang bertujuan untuk mengetahui hubungan antara dua variabel atau lebih yang mempunyai hubungan sebab akibat terhadap variabel lainnya. Dengan penelitian ini, dapat dibangun suatu teori yang berfungsi untuk menjelaskan, meramalkan dan mengontrol suatu gejala.

Populasi dalam penelitian ini adalah pasien yang berobat ke Puskesmas Cibitung Kabupaten Sukabumi dari bulan Januari sampai bulan September 2018. Teknik sampling yang digunakan adalah sampling kuota. Dalam menentukan jumlah ukuran sampel yang akan diambil dalam penelitian ini, peneliti menggunakan rumus Slovin dalam (Umar, 2002: 14). Penentuan ukuran sampel menggunakan rumus Slovin:

Keterangan:

$$
n=\frac{N}{1+\mathrm{N}(\mathrm{e}) 2}
$$

$n=$ unit sampel (jumlah responden yang dibutuhkan).

$\mathrm{N}=$ populasi (jumlah ukuran populasi).

$\mathrm{e}=$ nilai eror yang digunakan .

Peneliti menentukan nilai eror/ presentase kelonggaran ketidaktelitian tingkat kesalahan sebesar $10 \%$, jadi jumlah yang dapat diambil berdasarkan rumus di atas adalah sebagai berikut:

$$
\begin{aligned}
n & =\frac{14430}{1+14430(0.01)} \\
& =\frac{14430}{1+144,30} \\
& =\frac{14430}{145,30} \\
& =99,31 \text { dibulatkan menjadi } 99 .
\end{aligned}
$$

Berdasarkan perhitungan di atas, maka jumlah seluruh sampel yang diambil adalah 99 orang. Dalam menentukan sampel, penulis memberikan kriteria yang akan menjadi responden adalah pasien yang berobat ke Puskesmas Cibitung sehingga dapat memberi penilaian mengenai kualitas pelayanan di Puskesmas Cibitung Kabupaten Sukabumi 
Teknik pengumpulan data yang dilakukan oleh peneliti adalah studi literatur atau kepustakaan, dan studi lapangan yaitu teknik pengumpulan data dengan menggunakan angket atau kuesioner. Teknik pengukuran data dilakukan dengan menggunakan pengukuran skala Likert. Menurut Sugiyono (2011: 107), skala Likert digunakan untuk mengukur sikap, pendapat, persepsi seseorang atau kelonpok tentang fenomena sosial. Skala Likert ini digunakan dalam pengisian kuesioner. Data yang telah terkumpul melalui angket, kemudian penulis olah ke dalam bentuk kuantitatif, yaitu dengan cara menetapkan skor jawaban dari pernyataan yang telah dijawab oleh responden, dimana pemberian skor tersebut didasarkan pada ketentuan jumlah jawaban (Tabel 2).

Tabel 2. Alternatif Jawaban dan Bobot Nilai

\begin{tabular}{lc}
\hline Alternatif Jawaban & Bobot Nilai $(+)$ \\
\hline Sangat Setuju & 5 \\
\hline Setuju & 4 \\
\hline Ragu-ragu & 3 \\
\hline Tidak Setuju & 2 \\
\hline Sangat Tidak Setuju & 1 \\
\hline Sumber: Sugiyono $(2017: 94)$
\end{tabular}

Sumber: Sugiyono (2017: 94)

Dalam pengujian instrumen penelitian, peneliti menggunakan Uji Validitas dan Uji Reliabilitas. Teknik analisis data menggunakan Analisis Regresi Linear Sederhana dan Analisi Koefisien Determinasi. Untuk pengujian hipotesis, peneliti menggunakan Uji Koefisien Regresi secara parsial (uji t) dan Koefisien Korelasi.

\section{HASIL DAN PEMBAHASAN}

\section{Uji Validitas}

Uji validitas menunjukkan suatu ukuran tingkat kevalidan atau ketetapan suatu instrumen. Suatu instrumen yang valid mempunyai validitas yang tinggi. Sebaliknya, instrumen yang kurang valid berarti memiliki validitas rendah. Valid berarti instrumen tersebut dapat digunakan untuk mengukur apa yang seharusnya diukur. Pengujian validitas dilakukan dengan melakukan uji dua sisi dengan taraf signifikansi 0,05.

Kriteria pengujian adalah sebagai berikut:

1) Jika $r$ hitung $>r$ tabel (uji dua sisi dengan sig. 0,05) maka instrumen atau item-item pernyataan berkorelasi signifikan terhadap skor total (dinyatakan valid).

2) Jika $r$ hitung $<r$ tabel (uji dua sisi dengan sig. 0,05) maka instrumen atau item-item pernyataan tidak berkorelasi signifikan terhadap skor total (dinyatakan tidak valid).

Dari hasil analisis didapatkan nilai korelasi antar skor item dengan skor total. Nilai ini kemudian dibandingkan dengan nilai $r$ tabel, $r$ tabel dicari pada signifikansi 0,05 dengan uji dua sisi dan jumlah data $\mathrm{n}=99$, maka didapat $r$ tabel sebesar 0,195.

Berikut ini dapat dilihat hasil dari perhitungan validitas untuk keseluruhan butir pernyataan (Tabel 3).

Tabel 3. Hasil Perhitungan Validitas

\begin{tabular}{|c|c|c|c|c|}
\hline Variabel & Item & r Hitung & r Tabel & Keterangan \\
\hline \multirow{24}{*}{$\begin{array}{l}\text { Kualitas } \\
\text { Pelayanan } \\
\text { (X) }\end{array}$} & 1 & 0,459 & 0,195 & Valid \\
\hline & 2 & 0,212 & 0,195 & Valid \\
\hline & 3 & 0,518 & 0,195 & Valid \\
\hline & 4 & 0,528 & 0,195 & Valid \\
\hline & 5 & 0,296 & 0,195 & Valid \\
\hline & 6 & 0,279 & 0,195 & Valid \\
\hline & 7 & 0,359 & 0,195 & Valid \\
\hline & 8 & 0,435 & 0,195 & Valid \\
\hline & 9 & 0,483 & 0,195 & Valid \\
\hline & 10 & 0,450 & 0,195 & Valid \\
\hline & 11 & 0,525 & 0,195 & Valid \\
\hline & 12 & 0,496 & 0,195 & Valid \\
\hline & 13 & 0,558 & 0,195 & Valid \\
\hline & 14 & 0,551 & 0,195 & Valid \\
\hline & 15 & 0,449 & 0,195 & Valid \\
\hline & 16 & 0,378 & 0,195 & Valid \\
\hline & 17 & 0,349 & 0,195 & Valid \\
\hline & 18 & 0,456 & 0,195 & Valid \\
\hline & 19 & 0,522 & 0,195 & Valid \\
\hline & 20 & 0,447 & 0,195 & Valid \\
\hline & 21 & 0,348 & 0,195 & Valid \\
\hline & 22 & 0,399 & 0,195 & Valid \\
\hline & 23 & 0,352 & 0,195 & Valid \\
\hline & 24 & 0,428 & 0,195 & Valid \\
\hline \multirow{8}{*}{$\begin{array}{l}\text { Kepuasan } \\
\text { Pasien (Y) }\end{array}$} & 25 & 0,473 & 0,195 & Valid \\
\hline & 26 & 0,460 & 0,195 & Valid \\
\hline & 27 & 0,350 & 0,195 & Valid \\
\hline & 28 & 0,463 & 0,195 & Valid \\
\hline & 29 & 0,414 & 0,195 & Valid \\
\hline & 30 & 0,489 & 0,195 & Valid \\
\hline & 31 & 0,474 & 0,195 & Valid \\
\hline & 32 & 0,447 & 0,195 & Valid \\
\hline
\end{tabular}




\begin{tabular}{lllll}
\hline 33 & 0,449 & 0,195 & Valid \\
\cline { 2 - 5 } 34 & 0,458 & 0,195 & Valid \\
\hline 35 & 0,452 & 0,195 & Valid \\
\hline 36 & 0,413 & 0,195 & Valid \\
\hline 37 & 0,412 & 0,195 & Valid \\
\hline 38 & 0,400 & 0,195 & Valid \\
\hline
\end{tabular}

Sumber: Hasil Perhitungan Validitas, 2019

Berdasarkan hasil analisis, didapatkan nilai korelasi item-item yang nilainya lebih dari 0,195 sehingga dapat disimpulkan bahwa butir instrumen penelitian Kualitas Pelayanan (X) dan Kepuasan Pasien (Y) dinyatakan valid.

\section{Uji Reliabilitas}

Uji Realiabilitas adalah menguji apakah hasil kuesioner atau angket dapat dipercaya atau tidak. Pengujian realibilitas instrumen dapat dilakukan secara eksternal maupun internal. Secara eksternal dapat dilakukan dengan test retest (stability), eguivalent, dan gabungan keduanya. Uji reliabilitas merupakan kelanjutan dari uji validitas, dimana item yang diuji adalah hanya item yang valid.

Uji reliabilitas dilakukan pada taraf signifikan 0,05, artinya intrumen dapat reliabel apabila nilai alpha besar $(>)$ dari $r$ kritis product moment. Maka item-item angket yang digunakan relibel atau konsisten. Berdasarkan hasil pengolahan data dengan menggunakan bantuan SPSS, diperoleh hasil reliabilitas sebagaimana ditunjukkan pada Tabel 4.

Tabel 4. Hasil Uji Reliabilitas Reliability Statistics

\begin{tabular}{cr}
\hline Cronbach's Alpha & N of Items \\
\hline, 880 & 38 \\
\hline
\end{tabular}

Sumber: Hasil Pengujian Reliabilitas, Output SPSS 22, 2019

Dari hasil pengelohan SPSS 22, maka diperoleh nilai alpha sebesar 0,880 . Karena nilai Cronbach alpha lebih besar dari 0,70 $(0,880>0,70)$, maka dapat disumpulkan bahwa variabel Kualitas Pelayanan dan Kepuasan Pasien dapat dikatakan riliabel dan dapat digunakan untuk mengujian selanjutnya.

\section{Analisis Regresi Linear Sederhana}

Analisis regresi linear sederhana adalah salah satu alat analisis yang digunakan untuk mengetahui arah hubungan antara variabel independen (X) yaitu kualitas pelayanan terhadap variabel dependen (Y) yaitu kepuasan pasien, apakah positif atau negatif, dan untuk memprediksikan nilai dari variabel dependen apabila nilai variabel independen mengalami kenaikan atau penurunan. Berdasarkan hasil pengolahan data dengan bantuan Software SPSS 22, diperoleh hasil sebagaimana ditunjukkan pada Tabel 5.

Tabel 5. Hasil Analisis Regresi Linear Sederhana

\begin{tabular}{|c|c|c|c|c|c|}
\hline \multicolumn{6}{|c|}{ Coefficients $^{\mathrm{a}}$} \\
\hline \multirow{4}{*}{ Model } & Unstand & ardized & Standardized & \multirow[b]{4}{*}{$\mathrm{t}$} & \multirow[b]{4}{*}{ Sig. } \\
\hline & \multicolumn{2}{|c|}{ Coefficients } & Coefficients & & \\
\hline & & Std. & & & \\
\hline & B & Error & Beta & & \\
\hline 1 (Constant) & 12,378 & 3,733 & & 3,316 & ,001 \\
\hline $\begin{array}{l}\text { KUALITAS } \\
\text { PELAYANAN }\end{array}$ & ,456 & ,038 & ,772 & 11,955 & ,000 \\
\hline a. Dependent Va & ble: KE & JASAN & ASIEN & & \\
\hline
\end{tabular}

Berdasarkan hasil analisis regresi sederhana yang telah dilakukan, maka dalam penelitian ini didapat model fungsi regresi sebagai berikut:

$$
\begin{aligned}
\mathrm{Y}^{1} & =\mathrm{a}+\mathrm{bx} \\
& =12,378+0,456
\end{aligned}
$$

Keterangan:

$\mathrm{Y}^{1}=$ Kepuasan Pasien

$\mathrm{X}=$ Kualitas Pelayanan

Pada persamaan regresi tersebut dapat dilihat bahwa koefisien regresi memiliki tanda positif yang berarti semakin baik kualitas pelayanan, maka kepuasan pasien meningkat, begitupun sebaliknya, apabila kualitas pelayanan kurang baik maka kepuasan pasien akan menurun.

Dari tabel di atas, didapat informasi:

1) Konstanta (a) sebesar 12,378, artinya jika kualitas pelayanan nilainya 0 , maka kepuasan pasien nilainya 12,378 .

2) Koefisien regresi intensifikasi kualitas pelayanan (b) bernilai positif, yaitu 0,456 , artinya setiap pelaksanaan kualitas pelayanan bernilai 1, maka kepuasan pasien akan meningkat 0,456 . 


\section{Analisis Koefisien Determinasi}

Analisis koefisien determinasi adalah untuk menunjukkan seberapa persen besarnya pengaruh Kualitas Pelayanan terhadap Kepuasan Pasien di Puskesmas Cibitung Kabupaten Sukabumi. Koefisien determinasi diolah dengan menggunakan SPSS 22 (Tabel 6).

Tabel 6. Analisis Koefisien Determinasi

\begin{tabular}{ccccc}
\hline \multicolumn{5}{c}{ Model Summary } \\
\hline Model & $\mathrm{R}$ & R Square & $\begin{array}{c}\text { Adjusted R } \\
\text { Square }\end{array}$ & $\begin{array}{c}\text { Std. Error of } \\
\text { the Estimate }\end{array}$ \\
\hline 1 &, $772^{\text {a }}$ &, 596 &, 592 & 3,17954 \\
\hline a. Predictors: (Constant), KUALITAS PELAYANAN
\end{tabular}

Berdasarkan tabel di atas diperoleh angka $\mathrm{R}^{2}$ (R Square) sebesar 0,596 atau $(59,6 \%)$. Hal ini menunjukkan bahwa persentase sumbangan pengaruh variabel kualitas pelayanan terhadap variabel kepuasan pasien sebesar 59,6\%. Sedangkan sisanya sebesar 40,4\% dipengaruhi atau dijelaskan oleh variabel lain yang tidak teliti oleh peneliti.

Berdasarkan tabel di atas, maka dapat diketahui bahwa nilai koefisien (R) adalah sebesar 0,772 .

$$
\begin{aligned}
& K d=R^{2} \times 100 \% \\
& K d=(0,772)^{2} \times 100 \%=59,6 \%
\end{aligned}
$$

Tabel 7. Interpretasi Koefisien Determinasi

\begin{tabular}{|c|c|}
\hline $0 \% \leq \mathrm{KD} \leq 100 \%$ & Tingkat Hubungan \\
\hline $81 \%-100 \%$ & Sangat tinggi \\
\hline $49 \%-80 \%$ & Tinggi \\
\hline $17 \%-48 \%$ & Cukup tinggi \\
\hline $5 \%-16 \%$ & Rendah tapi pasti \\
\hline $0 \%-4 \%$ & Rendah atau lemah sekali \\
\hline
\end{tabular}

Sumber: Sugiyono (2013: 183)

Dari tabel di atas jelas terlihat bahwa nilai koefisien determinasi yang telah dihitung sebesar 59,6\%, maka termasuk dalam kriteria berpengaruh tinggi. Sehingga dapat disimpulkan bahwa terjadi pengaruh yang tinggi dari kualitas pelayanan terhadap kepuasan pasien di Puskesmas Cibitung Kabupaten Sukabumi.

\section{Uji Koefisien Regresi Secara Parsial}

Uji parsial atau biasa disebut dengan uji t adalah suatu uji yang dilakukan untuk mengetahui apakah kualitas pelayanan berpengaruh signifikan atau tidak terhadap tingkat kepuasan pasien. Pengujian ini menggunakan tingkat signifikansi 0,05 dan 2 sisi.

Dalam penelitian ini, terdapat hipotesis sebagai berikut:

Ho = Tidak terdapat pengaruh kualitas pelayanan terhadap kepuasan pasien di Puskesmas Cibitung Kabupaten Sukabumi.

$\mathrm{Ha}=$ Terdapat pengaruh kualitas pelayanan terhadap kepuasan pasien di Puskesmas Cibitung Kabupaten Sukabumi.

Berikut ini hasil pengolahan uji $t$ dengan menggunakan program SPSS 22 (Tabel 8).

Tabel 8. Uji t Hasil U

\begin{tabular}{|c|c|c|c|c|c|}
\hline \multicolumn{6}{|c|}{ Coefficients $^{\mathrm{a}}$} \\
\hline \multirow[b]{2}{*}{ Model } & $\begin{array}{l}\text { Unstanda } \\
\text { Coeffici }\end{array}$ & $\begin{array}{l}\text { ardized } S \\
\text { ients }\end{array}$ & $\begin{array}{c}\text { Standardized } \\
\text { Coefficients }\end{array}$ & \multirow[b]{2}{*}{$\mathrm{t}$} & \multirow[b]{2}{*}{ Sig. } \\
\hline & B & $\begin{array}{l}\text { Std. } \\
\text { Error }\end{array}$ & Beta & & \\
\hline 1 (Constant) & 12,378 & 3,733 & & 3,316 &, 001 \\
\hline $\begin{array}{l}\text { KUALITAS } \\
\text { PELAYANAN }\end{array}$ & ,456 & ,038 & ,772 & 11,955 & ,000 \\
\hline
\end{tabular}
Coefficients

Berdasarkan hasil perhitungan menggunakan program SPSS 22 di atas, dapat dilihat nilai t hitung 11,955 dan nilai signifikansi 0,000. Selanjutnya dapat dilihat $\mathrm{t}$ tabel statistik pada signifikasi 0,05/2 = 0,025 , dengan derajat kebebasan df (n-2) / (99-2 =97), maka diperoleh $\mathrm{t}$ tabel untuk $\mathrm{t}$ tabel sebesar 1,988 . Oleh karena nilai $\mathrm{t}$ hitung $>\mathrm{t}$ tabel $(11,955>1,988)$ maka Ho ditolak. Dapat disimpulkan bahwa secara parsial, terdapat pengaruh yang signifikan antara Kualitas Pelayanan terhadap Kepuasan Pasien di Puskesmas Cibitung Kabupaten Sukabumi.

\section{Analisis Korelasi}

Analisis korelasi digunakan untuk mengetahui hubungan antara dua variabel atau lebih. Variabel independen dalam penelitian ini yaitu kualitas pelayanan, 
sedangkan variabel dependen yaitu kepuasan pasien. Berdasarkan hasil pengolahan data yang menggunakan korelasi Product Moment Pearson dengan bantuan software SPSS 22.0 for Windows, maka diperoleh hasil sebagaimana ditunjukkan pada Tabel 9.

Tabel 9. Hasil Uji korelasi

\begin{tabular}{|c|c|c|c|}
\hline \multicolumn{4}{|c|}{ Correlations } \\
\hline & & $\begin{array}{c}\text { Kualitas } \\
\text { Pelayanan }\end{array}$ & $\begin{array}{c}\text { Kepuasan } \\
\text { Pasien }\end{array}$ \\
\hline $\begin{array}{l}\text { KUALITAS } \\
\text { PELAYANAN }\end{array}$ & $\begin{array}{l}\text { Pearson } \\
\text { Correlation }\end{array}$ & r &, $772^{* *}$ \\
\hline & Sig. (2-tailed) & &, 000 \\
\hline & $\mathrm{N}$ & 99 & 99 \\
\hline $\begin{array}{l}\text { KEPUASAN } \\
\text { PASIEN }\end{array}$ & $\begin{array}{l}\text { Pearson } \\
\text { Correlation }\end{array}$ &, $772^{* *}$ & 1 \\
\hline & Sig. (2-tailed) & , 000 & \\
\hline & $\mathrm{N}$ & 99 & 99 \\
\hline
\end{tabular}

Tabel 10. Pedoman Interpretasi Koefisien Korelasi

\begin{tabular}{cc}
\hline $\begin{array}{c}\text { Interval } \\
\text { Koefisien }\end{array}$ & $\begin{array}{c}\text { Tingkatan } \\
\text { Hubungan }\end{array}$ \\
\hline $0,00-0,19$ & Sangat Rendah \\
\hline $0,20-0,39$ & Rendah \\
\hline $0,40-0,59$ & Sedang \\
\hline $0,60-0,79$ & Kuat \\
\hline $0,80-1,00$ & Sangat Kuat \\
\hline
\end{tabular}

Sumber: Sugiyono (2017: 184)

Berdasarkan Tabel 10 di atas, dapat dilihat bahwa nilai koefisien korelasi kualitas pelayanan dengan kepuasan pasien adalah sebesar 0,772. Hal tersebut menunjukkan bahwa terdapat hubungan yang sangat kuat antara kualitas pelayanan dengan kepuasan pasien di Puskesmas Cibitung Kabupaten Sukabumi.

\section{KESIMPULAN DAN REKOMENDASI}

\section{Kesimpulan}

Hasil penelitian membuktikan bahwa terdapat hubungan pengaruh yang kuat terhadap kepuasan pasien di Puskesmas Cibitung Kabupaten Sukabumi, yaitu dengan koefisien regresi kualitas pelayanan bernilai positif sebesar 0,456 , artinya setiap kualitas pelayanan bernilai 1, maka kepuasan pasien sebesar 0,456. Dalam uji t, diperoleh nilai $\mathrm{t}$ hitung $>\mathrm{t}$ tabel $(11,955>$ 1,988), artinya bahwa secara parsial terdapat pengaruh yang signifikan antara kualitas pelayanan terhadap kepuasan pasien di Puskesmas Cibitung Kabupaten Sukabumi. Berdasarkan hasil analisis korelasi diperoleh $\mathrm{R}$ sebesar 0,772, yang menunjukkan bahwa terdapat hubungan yang kuat antara kualitas pelayanan dengan kepuasan pasien. Berdasarkan koefisien determinasi diperoleh angka $\mathrm{R}$ square sebesar 0,596 atau $(59,6 \%)$ yang menunjukkan bahwa presentase sumbangan pengaruh variabel kualitas pelayanan terhadap kepuasan pasien sebesar 59,6\% termasuk dalam kriteria yang berpengaruh tinggi.

\section{Rekomendasi}

Peneliti menyarankan kepada peneliti selanjutnya untuk dapat mengadakan penelitian yang mendalam dengan cakupan layanan yang lebih luas mengenai kualitas pelayanan terhadap kepuasan pasien, berdasarkan fenomena yang ada guna menghasilkan penelitian baru dengan hasil yang lebih baik serta lebih berguna bagi masyarakat dan insttansi terkait.

Berkaitan dengan hasil penelitian kualitas pelayanan terhadap kepuasan pasien di Puskesmas Cibitung Kabupaten Sukabumi, peneliti menyarankan hal-hal sebagai berikut:

1) Pihak Puskesmas Cibitung Kabupaten Sukabumi harus meningkatkan dimensi assurance (jaminan), yaitu memberikan pelayanan dengan tepat waktu dan memberikan kenyamanan seperti ramah dalam melayani pasien sesuai $5 \mathrm{~S}$ (senyum, salam, sapa, sopan, santun).

2) Meningkatkan fasilitas Puskesmas Cibitung Kabupaten Sukabumi untuk kenyamanan pasien yang berkunjung, dengan menambah satu ruangan khusus poli gigi agar tidak bersatu dengan ruang IGD.

3) Meningkatkan kepuasan pasien, karena kepuasan pasien merupakan tujuan utama dan sebuah pelayanan. Oleh karena itu, untuk meningkatkan kepuasan pasien, Kepala Puskesmas Cibitung Kabupaten Sukabumi dapat melakukan perbaikan yang optimal dan 
menyeluruh terhadap semua aspek yang menyangkut kualitas pelayanan dengan cara memberikan pengarahan dan kontrol kepada semua pegawai serta meningkatkan kinerja demi tercapainya pelayanan yang lebih memuaskan bagi pasien yang berobat.

\section{DAFTAR PUSTAKA}

\section{Buku:}

Black, James dan Champion, Dean J. 2009. Metode \& Masalah Penelitian Sosial. Bandung: Refika Aditama.

Engkus. 2017. Administrasi Kepegawaian Indonesia Pada Sektor Publik (Dalam Pendekatan Aparatur Sipil Negara). Bandung: FISIP UNPAS Press.

Harbani, Pasolong. 2013. Teori Administrasi Publik. Bandung: Alfabeta.

Hariwijaya, Triton. 2013. Pedoman Penulisan Ilmiah Skripsi \& Tesis. Yogyakarta: PLATINUM.

Hardiyansyah. 2011. Kualitas Pelayanan Publik, Konsep, Dimensi, Indikator dan Implementasinya. Yogyakarta: Gava Media.

Hermawan, R. dan Zen, Z. 2006. Etika Kepustakawanan: Suatu Pendekatan terhadap Profesi dan Kode Etik Pustakawan Indonesia. Jakarta: Sagung Seto.

Ibrahim, Amin. 2008. Teori dan Konsep Pelayanan Publik serta Implementasinya. Bandung: Mandar Maju.

Kotler, Philip dan Keller, Kevin Lane. 2009. Manajemen Pemasaran. Jakarta: Erlangga.

Lasa, H. S. 2013. Manajemen Perpustakaan. Yogyakarta: Ombak.

Moenir, HAS. 2010. Manajemen Pelayanan Umum Di Indonesia. Jakarta: Bumi Aksara.

Moleong, Lexy J. 2013. Metodologi Penelitian Kualitatif. Bandung: Remaja Rosdakarya.
Pandian, Paul. 2001. RFId for Libraries A Partical Guide. New Delhi: Chandos Publishing.

Pohan, Imbalo S. 2015. Jaminan Mutu Layanan Kesehatan. Jakarta: Buku Kedokteran EGC.

Siagian, Sondang P. 2001. Kerangka Dasar Ilmu Administrasi. Jakarta: Rineka Cipta.

Sugiyono. 2008. Metodologi Penelitian Bisnis (Pendekatan Kuantitatif, Kualitatif, dan R\&D). Bandung: Alfabeta.

--------. 2009. Metode Penelitian Bisnis (Pendekatan Kuantitatif, Kualitatif, dan $R \& D$ ). Bandung: Alfabeta.

----------. 2011. Metode Penelitian Kuantitatif Kualitatif dan R\&D. Bandung: Alfabeta.

---------. 2013. Metode Penelitian Bisnis (Pendekatan Kuantitatif, Kualitatif, dan $R \& D$ ). Bandung: Alfabeta.

----------. 2014. Metode Penelitian Administrasi. Bandung: Alfabeta.

---------. 2017. Metode Penelitian Kuantitatif, Kualitatif, dan R\&D, Bandung: Alfabeta.

Syafiie, Inu Kencana. 2010. Ilmu Administrasi Publik. Jakarta: Rineka Cipta.

--------------------------. 2011. Sistem Administrasi Negara Republik Indonesia (SANRI), Bandung: Bumi Aksara.

Tjiptono, Fandy. 2008. Service Management: Mewujudkan Layanan Prima. Yogyakarta: Andi.

\section{Skripsi/Jurnal:}

Engkus. 2017. Kepuasan Kerja Dalam Kajian Administrasi Publik. Diakses dari: https://scholar.google.co.id/citations ?user=c3to4JwAAAAJ\&hl=id, pada 18 Oktober 2018.

Herwanto, Heri. 2018. Pengaruh Kualitas Pelayanan Kesehatan terhadap 
Kepuasan Pasien di Puskesmas

Simeuleu Timur. Diakses dari: repository.ut.ac.id, pada 10 Oktober 2018.

Meliana, Dewi. 2017. Pengaruh Kualitas Pelayanan pada Kepuasan Pasien di Puskesmas Rawat Inap Mas Makmur Kabupaten Mesuji Provinsi Lampung. Diakses dari: digilib.unila.ac.id, pada 19 Oktober 2018.

Suparman, N. 2017. Kualitas Pelayanan Izin Mendirikan Bangunan (IMB) pada Badan Pelayanan Perizinan Terpadu Dan Penanaman Modal Kabupaten Cianjur. Jurnal Borneo Administrator [Online], available from: doi:10.24258/jba.v13.274.

Wandani, Fitrilia. 2018. Pengaruh Kualitas Pelayanan terhadap Kepuasan Pasien di Puskesmas Cibitung Kabupaten Sukabumi. (Skripsi). Administrasi Publik FISIP Universitas Islam Negeri Sunan Gunung Djati Bandung.

\section{Peraturan Perundang-undangan:}

Peraturan Pemerintah Nomor Tahun 2005 tentang Penyusunan dan Penerapan Standar Pelayanan.

Undang-Undang Nomor 25 Tahun 2009 tentang Pelayanan Publik.

Undang-Undang Nomor 36 Tahun 2009 tentang Fasilitas Kesehatan. 